\title{
УКРАИНСКИЙ КРИЗИС КАК СЛЕДСТВИЕ ПОЛИТИКИ ЕС И НАТО ПО СОЗДАНИЮ ПОЯСА СТРАТЕГИЧЕСКОГО ОКРУЖЕНИЯ РОССИИ
}

\begin{abstract}
Аннотация: Украинский кризис, развязка которого, по всей видимости, еще не наступила, стал кульминацией нарастания противоречий между Россией и странами западного сообщества. Политика сдерживания, окружения, ослабления России, насчитывающая не одно столетие, в начале XXI века достигла своего апогея. События на Майдане в столице Украины г. Киеве в этом плане сыграли роль точки бифуркации, определившие открыто конфронтационный характер, прежде всего, российско-американских отношений, а с учетом фактического протектората США над Европой, и российско-европейских. Более чем очевидно, что ни США, ни НАТО, ни тем более Евросоюзу Украина не нужна сама по себе, с ее радикально поляризованным 40-миллионным населением, стагнирующей экономикой и уровнем коррупции, не укладывающейся ни в какие индексы. Тем более, они не заинтересованы в продвижении в этой стране каких-либо демократических ценностей, предполагающих безусловное обеспечение прав человека.
\end{abstract}

Ключевые слова: международные отношения, внешняя политика, Россия, геополитика, Украина, мятеж, конфликт, США, НАТО, безопасность.

$\mathrm{Y}$ краинский кризис, развязка которого, по всей видимости, еще не наступила, стал кульминацией нарастания противоречий между Россией и странами западного сообщества. Политика сдерживания, окружения, ослабления России, насчитывающая не одно столетие, в начале XXI века достигла своего апогея. События на Майдане в столице Украины г. Киеве в этом плане сыграли роль точки бифуркации, определившие открыто конфронтационный характер, прежде всего, российско-американских отношений, а с учетом фактического протектората США над Европой, и российско-европейских. Более чем очевидно, что ни США, ни НАТО, ни тем более Евросоюзу Украина не нужна сама по себе с ее поляризованным 40-миллионным населением, стагнирующей экономикой и уровнем коррупции, не укладывающейся ни в какие индексы. Тем более, они не заинтересованы в продвижении в этой стране каких-либо демократических ценностей, предполагающих безусловное обеспечение прав человека.

Единственное на, что может рассчитывать Украина в ближайшей перспективе - это на «демократию по-иракски», с ее острейшими этноконфесиональными конфликтами, едва ли не ежедневными терактами и прочими атрибутами хаоса. Это, в общем-то, и есть те «ценности», которые на самом деле продвигают и утверждают США и их сателлиты, посредством разного рода цветных революций на территориях других стран, не относящихся к евроатлантическому сообществу, таких например, как Ирак, Афганистан, Тунис, Египет, Ливия, Йемен и другие. В ближайшей перспективе этот перечень государств с уже утвержденными «демократическими ценностями», по всей видимости, дополнит и Украина.

Еще одним вариантом развития ситуации здесь может быть утверждение демократии «погрузински» эпохи М. Саакашвили с ее витринным благополучием и произволом во внутренней и внешней политике. Но для достижения этого состояния необходимо, по крайней мере, пройти тот путь, который прошла Грузия за десятилетие до утверждения М. Саакашвили у власти. И, прежде всего, поставить под контроль все незаконные вооруженные формирования. В Грузии это были отряды Мхедриони, осуществившие в 1992 году вооруженное вторжение в Абхазию и тем самым спровоцировавшие острейшую вооруженную фазу грузино-абахазского конфликта. На Украине аналогом «Мхедриони» являются пробандеровские формирования «правого сектора», позиционирующие себя в качестве «самообороны Майдана». При этом также как и в Грузии начала 90-х эти формирования фактически подменили собой государственные силовые структуры, и именно они вершат суды (самосуды) от имени народа как в столице Украины, так и в других регионах страны. Официальным структурам Киева остается только принимать это априори, поскольку сейчас эти отряды выступают 
в роли «священной коровы» и им дозволено все, в том числе и откровенный бандитизм, учитывая их заслуги перед Майданом. Тем не менее, будущее их уже предопределено: им дадут «побузить» а потом проведут в отношении них ночь «хрустальных ножей», точно также как в отношении левых эсеров в 1918 году, махновцев в 1920 году, или же штурмовиков Рэма в 1934 году в Германии. Они свое дело сделали, и поэтому должны быть уничтожены, поскольку ввиду тех же заслуг представляют реальную опасность уже для новой власти в Киеве.

Как долго это будет продолжаться, знают только в американском посольстве в Киеве, поскольку именно здесь, также как и в Грузии, находится резиденция самого влиятельного политика в стране - американского посла, выражающего волю Госдепа США. Какова будет воля, такова и будет судьба и отрядов «самообороны Майдана», да и самопровозглашенного правительства Украины тоже.

В целом следует отметить, что у «бархатной революции» апреля 1989 года в Грузии и «майдановской» февраля 2014 года на Украине очень много общего, от антироссийских и пронатовских лозунгов, до ритуальных жертв.

Так же как и в Тбилиси, в Киеве антиправительственные действия осуществлялись под информационным и внешнеполитическим прикрытием США и их союзников, И там, и здесь власть продемонстрировала свою немощь. Попытки пресечь вооруженный переворот по аналогии были объявлены антинародными, а сотрудники силовых структур - вне закона.

Ну и, конечно же, самый главный признак, объединяющий эти события - это жертвы, принесенные на алтарь революции. В Тбилиси таковых было 18, затоптанных толпой и предъявленных в качестве результатов «неадекватного насилия» военнослужащими. Примечательно, что результаты официального расследования Генеральной прокуратурой событий в Тбилиси 9 апреля 1989 года, так и не были обнародованы, натолкнувшись на ожесточенное сопротивление представителей организаций, которые сейчас можно именовать как иностранные агенты. Зато этот день в Грузии объявлен памятным днем, и на месте трагедии возлагаются цветы, не исключено, что и непосредственными ее виновниками.

Число жертв в Киеве - сто человек, скончавшихся от пулевых ранений. Эти жертвы были вменены в вину режиму В. Януковича, который так и не отдал приказа о силовом пресечении беспорядков. В то же время информация об идентичности пулевых ранений у протестующих и милиции, а также непосредственной связи снайперов с лидерами Майдана, вызвала у комиссара ЕС баронессы К. Эштон отстраненную реакцию ${ }^{1}$. Предложение же руководству Евросоюза расследовать обстоятельства гибели мирных граждан и сил правопорядка, было проигнорировано. Это свидетельствует о незаинтересованности европейских чиновников высокого уровня в установлении истинных причин гибели украинских граждан. В этой связи остается предположить, что их гибель была фактически санкционирована лоббистами новой украинской власти из числа высшей европейской и американской бюрократии.

На самой же Украине, погибшие от рук снайперов, объявлены национальными героями - «небесной сотней» - и к месту их гибели возлагаются цветы, в том числе и теми, кто стоял за их убийством. С учетом же того, что значительная часть жертв погибла уже после того, когда стало очевидно, что оппозиция перехватывает власть, есть основания считать, что убийства людей были ритуальными с тем, чтобы легитимизировать вооруженный переворот, а сами события мифологизировать.

События в Киеве в очередной раз свидетельствуют о том, что цинизм становится доминирующим принципом внешней политики США и их союзников по НАТО и Евросоюзу. И это уже давно никого не удивляет, даже самих американцев. Как считает, например, бывший помощник Р. Рейгана Д. Бэндоу, «от лицемерия Запада захватывает дух». По его словам «и часа, не то, что дня, не проходит без того, чтобы Вашингтон не попытался подкупить или запугать правительство другой страны». Очевидно, свой час и свой день наступил и для бывшего руководства Украины, наступят они и для нового, если оно будет не меру самостийным.

Нельзя исключить также и то, что у Украины будет свой собственный путь утверждения «демократических ценностей», и в политический лексикон войдет понятие «демократия по-украински». Тем более, что традиции «махновщины» и «бандеровщины», как показали последние события, активно реанимируются. В политический лексикон, по всей видимости, войдет и такое понятие как «право майдана» с учетом того, что именно Майдан, а точнее толпа на Майдане определяет сегодня состав украинского правительства, основные

\footnotetext{
См.: МИД Эстонии подтвердил подлинность записи разговора между Паэтом и Эштон о событиях на Украине http:// russian.rt.com/article/23695
} 
приоритеты его деятельности, а также в целом внешне- и внутриполитический вектор развития Украины,

Но это уже не суть важно. Принципиально важно то, что переворот произошел и главная цель - дестабилизация ситуации на Украине - достигнута. Поэтому те 5 млрд. долл., которые по признанию помощника госсекретаря США В. Нуланд были вложены в «майдан»², себя окупили.

Важно также и то, что, к сожалению, очередная попытка создания собственной государственности у Украины так и не состоялась. Да, она и не могла состояться.

Отказавшись от своей истории периода Киевской Руси и нахождения в составе Российского государства, украинская власть всего периода «незалежности» сосредоточила усилия, во-первых, на личном (во что бы то ни стало) обогащении, а вовторых, на противопоставлении Украины России (Украина - не Россия).

Конечно же, Украина не Россия, которая на фундаменте той же Киевской Руси создала тысячелетнюю цивилизацию, и, дважды, по крайней мере, за последние два столетия спасала человечество от порабощения претендентами на мировое господство. И это является следствием многовекового российского государственного строительства.

Традицией же «незалежности» Украины является поиск спонсоров своей государственности. Так, было в 1918 году и 1920 году, когда Украина, получив фактическую независимость от Советской России, оказалась под протекторатом сначала Германии, а затем Польши. Так было и в более ранние периоды, когда наследник Б. Хмельницкого - Ю. Хмельницкий попытался отдать Украину под протекторат Турции, а И. Мазепа - Швеции.

Как показывают текущие события, эта традиция «подданичества» глубоко укоренилась в сознании украинского истеблишмента. Только сегодня его масштабы значительно крупнее. Речь идет о стремлении оказаться «под крышей» гегемона уже мирового масштаба - США, которое маскируется идеологемами о евроатлантической интеграции.

Это дает основание считать, что, как государство, Украина, так и не состоялась. И едва ли состоится в ближайшей или в какой-либо отдаленной перспективе. Причем эту позицию активно про-

\footnotetext{
2 См.: Признание официального представителя Госдепа: вложения в «майдан» \$5 млрд http://communitarian. ru/novosti/sng-i-sssr/priznanie_oficialnogo_predstavitelya_ godepa_vlozheniya_v_maydan_5_mlrd_07012014/
}

двигают и сами американцы, считая Украину - несостоявшимся государством ${ }^{3}$.

Причиной этого является отсутствие в этой стране национально (не националистически) ориентированных лидеров. У власти на Украине во все периоды ее «незалежности» находились «временщики», исповедующие всем известный принцип маркизы Помпадур «после нас хоть потоп (Après nous le déluge)». Временщиками являются и самопровозглашенные власти в Киеве, поскольку та сборная солянка в руководстве (баптист, боксер, националист и Яценюк), никоим образом не ориентирована на обеспечение суверенитета своей страны, который ими рассматривается исключительно как товар, который необходимо выгодно реализовать. Наиболее очевидным потребителем этого товара является евроатлантическое сообщество: США и позиционирующий свою самостоятельность Евросоюз, которые взамен гарантируют новой украинкой власти свою поддержку в противостоянии с Россией.

И в этой связи, очевидно, что все же главная причина последних событий на Украине обусловлена стремлением недопустить ее интеграцию с Россией по каким-либо направлениям.

Почти четверть века постсоветской истории стремление как можно дальше развести Украину и Россию, а по возможности и противопоставить их друг другу были и остаются лейтмотивом внешней политики США. Так, по словам гуру американской геополитики 3. Бжезинского «Украина является территорией, что лежит глубоко в сердце России. Поддержка политических сил в Украине для Соединенных Штатов является наиболее эффективным способом бороться против России» 4 .

Опасения возможной российско-украинской интеграции усилились в связи с активизацией интеграционных процессов на постсоветском пространстве и возможным вовлечением в эти процессы Украины. Формирование Таможенного союза с перспективой его переформатирования в Евразийский в США, НАТО и ЕС вызвало сначала шок, а затем жесткую реакцию представителей Госдепартамента и высшей евробюрократии. Х. Клинтон, например, в бытность госсекретарем заявляла, что постарается этого не допустить. Пози-

\footnotetext{
3 См.: Фонд США признал Украину и Грузию несостоявшимися государствами http://newsland.com/news/detail/ id/1232463/

4 См.: Верноподданические мурашки Виталия Кличко http://polemika.com.ua/article-133823.html
} 
ция неприятия возможной интеграции отражена и в заявлениях ряда западных аналитиков. Так, по словам 3. Бжезинского, «... если Россия подчинит себе Украину, это создаст у Москвы впечатление, будто она в состоянии восстановить Советский Союз под новым именем - Евразийского союза» 5 . По словам же Э. Лукаса (главный редактор журнала «The Economist), «стремление России создать Евразийский союз представляет собой курс на реставрацию советской империи» ${ }^{6}$ И, даже генсек НАТО А. Расмуссен не удержался от комментариев по этому вопросу, отметив, что «возвращение Украины в лагерь России - это «не прямая угроза, но повод для беспокойства».

На противодействие интеграционным процессам на постсоветском пространстве и был направлен польско-шведский проект «Восточное партнерство». Кульминацией реализации этого проекта стал Вильнюсский саммит (28-29 ноября 2013 года), на котором должна была быть институционально оформлена ассоциация с Европейским Союзом шести постсоветских государств (Азербайджана, Армении, Белоруссии, Грузии, Молдовы и Украины). Отказ едва ли не в последний момент руководства Украины подписать данное Соглашение и стал фактически детонатором трагических событий в Киеве.

В то же время на фоне бурных событий на Украине осталось незамеченным то, что Соглашение об ассоциации с Европейским Союзом отказались подписывать и прагматичная Армения, и динамично развивающийся Азербайджан, не говоря уже о Белоруссии, участие которой в проекте было достаточно условным с тем, чтобы стравить ее с Россией. В результате Соглашение об ассоциации c EC подписали только два фактически наибеднейших государства постсоветского пространства Молдова и Грузия.

Таким образом, насаждаемый на постсоветском пространстве проект «Восточного партнерства» фактически провалился, его кураторы свою программу не выполнили даже на 50\%. Во многом это стало следствием того, что сама Программа реализовывалась по принципу не «за», а «против». В данном случае против интеграционных процессов на постсоветском пространстве.

Своим же отказом от подписания Соглашения руководство Украины поставило под сомнение со-

\footnotetext{
5 См.: Призрак Советского Союза до сих пор пугает Запад http://newsland.com/news/detail/id/1299147/

6 См.: там же.
}

стоятельность самого Европейского Союза, предложение об ассоциации с которым было отклонено. Евробюрократам необходимо было, во что бы то ни стало спасать свой имидж и реабилитировать себя в глазах «большого брата». Поскольку та нецензурная оценка их действий помощником госсекретаря США В. Нуланд, прозвучавшая в разговоре с американским послом на Украине Дж. Пайеттом по поводу событий на Майдане ${ }^{7}$, едва ли была случайной. Напротив, она отражала истинное отношение администрации США и к Евросоюзу как к вассальному образованию, и, соответственно, к чиновникам, ответственным за реализацию проекта «Восточное партнерство». Именно этим объясняется тот жесткий прессинг европейских комиссаров и представителей внешнеполитических ведомств ряда стран ЕС, которое на себе испытало руководство Украины в декабре 2013 - феврале 2014 годов.

При этом никого из высокопоставленных лоббистов Соглашения не смутил тот факт, что по данным соцопросов только 19 \% жителей страны выступали за евроинтеграцию, в то же время более чем в 2.5 раза (48\%) - за вступление в даже еще не учрежденный Евразийский Союз. Примечательно также и то, что безоговорочно стремление к евроинтеграции продемонстрировало население отсталых аграрных регионов Украины, в то время как ее экономически развитый юго-восток традиционно ориентирован на развитие интеграционных процессов на постсоветском пространстве.

Таким образом, речь идет не только об игнорировании позиции преобладающего населения страны, но и откровенном попрании всех тех демократических ценностей, продвижением которых якобы и занимается «большой брат» со своими европейскими чиновниками.

И, безусловно, правомерна в этой связи позиция относительно того, что это уже далеко не политика двойных стандартов. Это политика одного стандарта - собственных корыстных интересов, ради достижения которых США и их партнеры пойдут на любые нарушения и международного права, и собственного национального законодательства, не говоря уже о суверенитете самой Украины.

Суть этих интересов сводится, как выше было отмечено, к созданию пояса стратегического окружения России.

См.: Помощник госсекретаря США Виктория Нуланд оконфузилась на весь мир //Независимая газета. - 7 февраля 2014 г. 


\section{Международные отношения / International Relations}

Нужна не Украина, а ее территория - максимально приближенная к жизненно-важным центрам Российской Федерации. Поэтому речь в данном случае идет не об Украине как суверенном государстве, а об украинском военно-стратегическом направлении чрезвычайно уязвимом для России. Даже, если бы событий на Украине не было бы, то их необходимо было бы выдумать с тем, чтобы спровоцировать обострение российско-украинских отношений.

Украина на этой «великой шахматной доске» лишь пешка, которой без сожаления можно пожертвовать, чтобы поставить, по крайней мере «шах» России. И именно сейчас эта перспектива открылась, почему и было столь массированным участие европейских и американских официальных лиц в событиях на Майдане. При этом явственно просматривается военно-политическая подоплека подобного рода вовлеченности. Примечательно, что киевские события более чем активно комментировал генсек НАТО А. Расмуссен, что свидетельствует о заинтересованности руководства Альянса в соответствующем их развитии.

Это интерес обусловлен тем, что НАТО и ЕС звенья одной цепи (22 из 28 членов ЕС являются членами НАТО). Формально, являясь независимыми, эти структуры в то же время реализуют один и тот же сценарий в отношении России. В этой связи мало кто сомневается, что Украина будет втянута в более широкую военную договоренность со странами ЕС и, соответственно НАТО.

Об этом свидетельствуют и сами положения Соглашения об ассоциации, определяющие, что «стороны будут изучать потенциал военного и технического сотрудничества. Украина и Европейское оборонное агентство (ЕОА) наладят тесные контакты для обсуждения вопросов, связанных с совершенствованием военных возможностей, в частности вопросов технического характера».

Преамбула проекта Соглашения связывает Украину с «ещё большим сближением позиций по двусторонним региональным и международным вопросам, представляющим взаимный интерес», включая и Общую внешнюю политику и политику безопасности Европейского союза (CFSP), а также Общую политику безопасности и обороны (CSDP) - что подчёркивает военно-политический характер Соглашения.

Как отмечает Д. Кусинич (бывший американский конгрессмен), «хотя проект «Соглашения об ассоциации с EC» продвигается как экономическое благо для граждан Украины, похоже, в действительности, это оказывается «троянский конь» HATO, предполагающий масштабное расширение позиций альянса в этом регионе ${ }^{8}$ и получение доступа к стране, которая делит обширную границу с Россией. Речь в данном случае идет об Украине, восточные границы которой будут служить новым рубежом военно-политического противостояния НАTO - Россия.

Таким образом, реализуются основные положения американской геополитической концепции известной под названием «План (петля) анаконды». Истоки этой концепции относятся ко времени гражданской войны в США, когда северяне разработали план разгрома Юга под названием «Анаконда». Суть плана состояла в том, что от Конфедерации отсекались важные территории, ее окружали и путем постепенного удушения вынудили прекратить борьбу.

В отношении России положения этого «Плана», реализуются посредством образования вокруг российских границ цепи враждебных государств, сужении пространства политического маневра в отношениях со странами региона реализуются последовательно на протяжении всего постсоветского периода. И многое в этом плане уже достигнуто.

Так, Центрально-азиатский регион, ввергнутый в хаос посредством невнятных операций США и их союзников в Ираке и Афганистане, в ближайшие десятилетия будет являться зоной нестабильности, генерируя конфликты на всем Большом Востоке от Китая до Испании, и, конечно же, на сопредельных с Россией территориях. Здесь же сосредоточены основные полевые лагеря и полигоны по подготовке экстремистов для участия в цветных революциях по всему миру, в том числе и на постсоветском пространстве.

Примечательно также и то, что за время натовской операции в Афганистане производство и экспорт наркотиков из этой страны увеличилось в 10 раз. При этом более $80 \%$, производимых в Афганистане наркотиков, экспортируется по так называемому «северному пути» - через территорию России. Здесь же и оседает и значительная их часть. По всей видимости, нужно быть очень наивным, чтобы исключить непосредственное участие в этом натовских стратегов. И это тоже одно из звеньев «Плана анаконды» против России.

Если отбросить всю информационную составляющую обеспечения действий НАТО в Цен-

\footnotetext{
8 См.: Троянский конь НАТО под видом «украинской весны» http://www.newscom.md/rus/troyanskij-kon_-nato-podvidom-ukrainskoj-vesni.html
} 
трально-азиатском регионе, начиная с вторжения в Афганистан в 2001 году, американцы не столько боролись с мифической Аль-Каидой, сколько отрабатывали новые формы вооруженной борьбы и, соответственно, испытывали новые образцы вооружений. Таким образом, мифические талибы, с которыми якобы и сражались США и их союзники, по сути дела, выступали в роли «подопытных кроликов». Помимо этого, США необходимо было прогнать через локальные вооруженные конфликты военнослужащих своих союзников от Великобритании, Франции до Польши и Грузии. Это и были реальные цели и мотивы американской операции «Несокрушимая свобода» в Афганистане.

Более же масштабные цели эскалации напряженности США в Центральной Азии предполагали дефрагментацию политического пространства и разобщение исламского мира, инициирование межконфессиональной и межэтнической конфликтности по принципу разделяй и властвуй. Именно этот древнеримский постулат - divide et impera - определяет сегодня специфику политических процессов в этом регионе 9 .

Сопредельный Центральной Азии регион Ближний Восток и Северная Африка, где позиции России были традиционно сильны, был подвергнут «демократизации», посредством цветных революций в рамках, так называемой «арабской весны». То, что в Тунисе, Египте, Ливии, Йемене вооруженные перевороты происходили по тому же сценарию, что и на Украине, свидетельствует о том, что инициаторы и организаторы этих удаленных друг от друга по времени и пространству событий одни и те же лица и структуры. Примечательно, что единственной страной, где не было позволено произойти революции из цикла «арабской весны» стало королевство Бахрейн, куда сопредельными странами Саудовской Аравией и ОАЭ были попросту введены войска и, это не было расценено как антидемократический акт. Не удалось реализовать сценарий «цветной революции» и в Сирии, в том числе благодаря позиции Китая и России, не позволивших санкционировать внешнее вооруженное вмешательство под надуманным предлогом в сирийский конфликт. И это было, пожалуй, наибольшим провалом внешнеполитической стратегии США за последние два десятилетия. Что, в свою очередь объясняет ожесточенность американских официальных лиц в отношении позиции России в украинском кризисе.

9 См.: Бочарников И.В. Сирийский излом // Мир и политика http://mir-politika.ru/3097-siriyskiy-izlom.html
На Южном Кавказе у США имеется свой кавказский авианосец - Грузия. Примечательно в этом плане заявление известного своей русофобской позицией сенатора Р. Лугара, о том, что членство Грузии в НАТО укрепит положение США на Южном Кавказе, и отсюда они смогут контролировать север Кавказа и иранское направление. Исходя из этого членство Грузии в НАТО, по всей видимости, произойдет уже в ближайшей перспективе, о чем и заявил в начале марта 2014 года генсек НАТО А. Расмуссен.

Учитывая конфликтные отношения с республиками Абхазией и Южной Осетией этот «авианосец» со вступлением в НАТО получит широкие возможности и будет постоянным источником напряженности в регионе, распространяя ее и на Северный Кавказ.

Конечно же, нынешнее руководство Грузии, пришедшее на смену русофобу М. Саакашвили, едва ли заинтересовано в эскалации напряженности в грузино-российских отношениях. Напротив и президент Грузии Г. Маргелашвили, и премьер-министр И. Гарибашвили, позиционируют стремление к нормализации этих отношений. Но, далеко не они определяют внешнеполитический вектор развития страны, Без соответствующих санкций из Вашингтона никакого прогресса в них не будет. А в этом США не заинтересованы. Их интересует в регионе именно военно-политическая составляющая развития ситуации. Об этом свидетельствует тот факт, что в ходе последнего М. Саакашвили в Вашингтон в январе 2012 года была достигнута договоренность об углублении американо-грузинского сотрудничества в военной области. И хотя само по себе соглашение носит закрытый характер, тем не менее, судя по уже осуществляемым поставкам, оно предусматривает полномасштабное перевооружение грузинских вооруженных сил, включая оснащение их средствами ПВО, вертолетами, катерами, а также стрелковым вооружением. Все это дает основание, что Грузии еще долго не удастся выйти из роли американского авианосца на Кавказе.

Начинается давление на российскую Арктику. В этом плане неслучаен тот факт, что наиболее агрессивную антироссийскую позицию в украинском кризисе занимает Канада, демонстрируя недружественные действия, в том числе нападения на российских дипломатов. И дело здесь не только в том, что в Канаде проживает внушительная диаспора - выходцев с Украины, в том числе и тех, кто в годы Второй мировой войны воевал на стороне нацистов. 
Руководству Канады, в общем-то, все равно, кто будет у власти в Киеве и что будет с Украиной, но далеко не все равно, что обладателем значительных ресурсов Арктики является Россия. Ставка в данном случае делается на то, что руководству России, подвергаемой обструкции со стороны США и ЕС из-за своей позиции по украинскому кризису, едва ли будет дело до Арктики и этим можно очень выгодно воспользоваться.

Наиболее же опасным в военно-политическом отношении до последнего времени для России было северо-западное - балтийское - направление. Именно здесь все последние годы военная активность НАТО постоянно возрастала.

Только в 2012 году на территориях Польши и стран Прибалтики, включая территориальные воды Балтийского моря, было проведено 13 крупных учений, в ходе которых были задействованы силы и средства все трех компонентов объединенных вооруженных сил Альянса (сухопутный, воздушный, морской). Замыслы данных маневров основывались на противодействии «угрозе с Востока», а под вероятными противниками недвусмысленно понимались Россия и Беларусь.

В 2013 году в Балтийском регионе прошли сразу несколько натовских учений - «BALTOPS», «Saber Strike», «Baltic Eye», «Kevadtorm». Кульминацией военной активности блока НАТО у границ России стали учения в ноябре 2013 года «Стедфаст Джаз» («Крепкий джаз») на территории Польши, Литвы и Латвии. В ходе учений отрабатывались вопросы нанесения удара высокоточными средствами поражения по системе командных пунктов штаба Западного военного округа, штаба Балтийского флота, по аэродромной сети Западного военного округа, по железнодорожным магистралям; блокирование и уничтожение кораблей Балтийского флота, а также другие элементы оперативно-стратегического планирования.

Обращают на себя и крупнейшие в истории информационных технологий военные киберучения Cyber Coalition 2013, ставшие логическим продолжением Steadfast Jazz 2013. Их сценарий предусматривал, помимо отражения агрессии против Эстонии так же и отработку защиты стран НАТО от масштабного киберудара предполагаемого противника. В учениях были задействованы 33 государства (все члены НАТО плюс и не входящие в военный блок Финляндия, Австрия, Ирландия, Швеция и Швейцария).

Анализ деятельности НАТО за последние 5 лет наглядно убеждает в том, что в рамках большин- ства военных учений осуществлялась непосредственная подготовка военных действий против России. При этом балтийское направление как наиболее приближенное к территории России стало эпицентром военно-политической активности. Таковым оно и будет в ближайшей перспективе, если не удастся втянуть в НАТО Украину.

Если же все-таки состоится то, удастся не только «разгрузить» Польшу и страны Балтии от череды провокационных учений, которые будут перенесены на территорию Украины. Главное же то, что реализация «Плана анаконды» получит свое развитие - практически на всем западном направлении, за исключением белорусского, Россия будет окружена в большей мере недружественными государствами, имеющими к тому же территориальные претензии к России.

При этом исключительное значение обретают восточные и юго-восточные регионы Украины, без которых вся затеянная игра теряет свой смысл.

Что, касается востока Украины - то здесь исторически сосредоточен промышленный, ресурсный и, наконец, интеллектуальный центр, дающий почти 35\% ВВП страны (Донецкая область-12,8 $\%$, Днепропетровская-11,3 \%, Харьковская-6,1 \%, Луганская-4,6 \%) и фактически обеспечивающий жизнедеятельность остальных ее регионов. Для сравнения вся западная Украина - только порядка 12,5 \% (Львовская область-4.2\%, Ивано-Франковская-2,1\%, Ровенская-1,5\%, Закарпатская-1,4\%, Тернопольская-1,3\%, Черновицкая-1\%).

Главной уязвимостью востока Украины является его культурно-историческая, гуманитарная и, наконец, финансово-экономическая ориентированность на Россию. То, что эти связи будут разорваны, сомнений нет. Неслучайно, одним из первых нормативных актов, которые приняла (потом правда отложила) постмайдановская Рада, касался отмены закона о региональных языках. И это невзирая на положения Европейской хартии о региональных языках и языках меньшинств, ратифицированной Украиной еще в 2003 году.

Это свидетельствует о том, что важнейшим приоритетом деятельности нового украинского руководства будет дерусификация востока Украины, с тем, чтобы превратить его в краеугольный камень нового антирусского «санитарного кордона».

Гуманитарный геноцид будет дополнен экономическим геноцидом русскоязычного населения страны. Экономическая помощь Украине со стороны ЕС обусловлена условиями выполнения всех рекомендаций для нее МВФ. Они в свою оче- 
редь предполагают кардинальное повышение для населения цены на газ, а также снижение на 50\% социальных расходов, в том числе заработной платы бюджетникам и пенсий. С учетом того, что в настоящее время средняя зарплата составляет 150 долл., а пенсии порядка 100 долл., после того как они будут ополовинены, то, соответственно составят - 75 и 50 долл. То есть, по сути, в отношении населения Украины предлагается реализовать ту же «шоковую терапию» времен «раннего Ельцина», от последствий которой Россия не оправилась и по истечению двадцати лет.

Исходя из этого, вполне очевидной является перспектива гуманитарной катастрофы на востоке Украины. Это делается для того, чтобы свести положение людей до состояния, когда они будут думать только о том, как прокормить себя и своих близких и им будет абсолютно все равно, кто будет у власти в Киеве, и какая политика будет проводиться в отношении России.

В военно-стратегическом отношении распространение НАТО в восточную часть Украины значительно усилит угрозы военной безопасности Российской Федерации. Военный потенциал самого мощного в истории военного альянса приблизится вплотную к наиболее развитым и густонаселенным районам европейской части России на обширной протяженности границы. Таким образом, будет создан стратегический плацдарм, с которого в любой момент можно будет ожидать вторжения.

Юг Украины НАТО нужен для того, чтобы сделать Черное море натовским. При наличии баз в Румынии и Турции военный потенциал США и НАТО будет значительно усилен. Здесь же, по всей видимости, будут размещены и системы ПРО на платформах.

С утверждением господства на Черном море США и НАТО попытаются взять в клещи российский Северный Кавказ, отрезать его от остальной территории страны и будут продвигаться далее к источникам углеводородного сырья в Азербайджане и Казахстане, руководство которых также, очевидно будет подвергнуто «демократизации» путем очередной цветной революции, если откажется стать марионеточным. О том, что это вполне реальный сценарий развития ситуации свидетельствуют периодические информационные вбросы о «коррупционности кланов Алиевых и Назарбаевых», их нелегитимности и т.д.

Демократизации, очевидно, будет подвержено и руководство Турции. Причиной этого являются черноморские проливы Босфор и Дарданеллы.
США едва ли устраивает то, что всякий раз, когда интересы продвижения демократии, как, например, в ходе августовской авантюры М. Саакашвили, требуют присутствия в Черном море американских военных кораблей, для их прохода через проливы Босфор и Дарданеллы приходится испрашивать разрешение у Турции.

С учетом стремления доминировать по всему миру США подобного рода зависимость от своего союзника едва ли может их устраивать. США, руководствуясь известным англо-саксонским принципом: нет постоянных союзников и друзей, а есть только постоянные интересы, намерены сами контролировать черноморские проливы.

Исходя из этого, в перспективе следует ожидать, что перед руководством Турции будет поставлен выбор: или оно будет обеспечивать беспрепятственный проход американских кораблей через Босфор и Дарданеллы без всякого согласования, или это сделает уже другое руководство Турции.

Очевидно, руководство Турции осознает нависшую над ним опасность и пытается, с одной стороны, демонстрировать лояльность евроатлантическим идеалам, в том числе как показали события в Сирии, путем участия в сирийском конфликте на стороне антиправительственных войск. С другой стороны, принимаются меры по нейтрализации современного оружия революционеров - социальных сетей. С этой целью правительство Турции уже в ближайшее время намерено запретить использование гражданами страны социальных сетей Facebook, YouTube и Twitter, которые использовались участниками антиправительственных демонстраций в качестве средств распространения информации во время демонстраций в 2013 году.

Помимо этого были освобождены из тюрем бывший начальник генерального штаба вооруженных сил Турции, а также ряд других знаковых турецких политиков, осужденных по обвинению в подготовке государственного переворота. Принимаются и другие меры по консолидации турецкого общества.

Таким образом, украинский кризис инициированный «Восточным партнерством» решает далеко идущие и, в первую очередь, геостратегические задачи.

В этой связи, конечно же, особую значимость обретает Крым с его исключительным стратегическим положением. Без Крыма господство на Черном море невозможно и это осознает руководство США, НАТО и ЕС. Именно этим в большой мере и объясняется их нервная реакция на результаты референдума о присоединении Крыма и Севастополя к России. 


\section{Международные отношения / International Relations}

Украинский кризис, как лакмусовая бумажка высветил стратегические цели США, НАТО и Евросоюза во взаимоотношениях с Россией. И, если Россия была целью стратегического окружения и максимального ослабления, то Украина, а точнее события на ее территории, - средством достижения этой цели.

Развитие событий свидетельствует о том, что на данном этапе союзники своих целей не достигли, и главная их задача сейчас заключается в том, чтобы «сохранить лицо». В то же время нет сомнений в том, что очередные попытки стратегического окружения и ослабления России будут предприниматься и впредь. Поэтому к ним уже нужно готовиться. И, очевидно, в этом плане уместно высказывание железного канцлера О.Бисмарка: «Нам не дано строить отношения между другими великими державами по своему выбору, однако мы можем сохранить за собой свободу использовать отношения, складывающиеся без нашего участия и, возможно, помимо нашего желания, в соответствиями с требованиями нашей безопасности и в наших интересах» ${ }^{10} 1$..

Анализ развития украинского кризиса и угроз на его фоне безопасности России позволяет сделать ряд выводов.
Прежде всего, необходимо более целенаправленно работать с политическими элитами постсоветского пространства и не делать ставку на лиц, готовых в любой момент отказаться от России и ее поддержки.

Необходимо переосмыслить роль и значение союзников России в современных условиях. Трудно не согласиться со словами замечательного русского генерала и отца финской государственности К.Маннергейма о том что «слабый союзник приносит больше забот, чем от него можно получить помощи» ${ }^{11}$. К сожалению, позиция союзников России в решающий момент оказалась мягко говоря никакой.

Главный урок, которые необходимо извлечь из анализа событий в Киеве в феврале 2014 года заключается в том, чтобы воспретить зарубежным официальным лицам принимать участие в антиправительственных акциях. Любое участие в них должно рассматриваться как вмешательство во внутренние дела и, соответственно, как нарушение суверенитета государства. Следствием подобного рода действий должно быть объявление зарубежных участников подобного рода акций персонами «нон грата» с высылкой их из страны.

\section{Библиография}

1. МИД Эстонии подтвердил подлинность записи разговора между Паэтом и Эштон о событиях на Украине http://russian.rt.com/article/23695

2. Признание официального представителя Госдепа: вложения в «майдан» \$5 млрд http:// communitarian.ru/novosti/sng-i-sssr/priznanie_oficialnogo_predstavitelya_godepa_vlozheniya_v_ maydan_5_mlrd_07012014/

3. Фонд США признал Украину и Грузию несостоявшимися государствами http://newsland.com/news/ detail/id/1232463/

4. Верноподданические мурашки Виталия Кличко http://polemika.com.ua/article-133823.html

5. Призрак Советского Союза до сих пор пугает Запад http://newsland.com/news/detail/id/1299147/

6. Помощник госсекретаря США Виктория Нуланд оконфузилась на весь мир //Независимая газета. 7 февраля 2014 г.

7. Троянский конь НАТО под видом «украинской весны» http://www.newscom.md/rus/troyanskij-kon_nato-pod-vidom-ukrainskoj-vesni.html

8. Бочарников И.В. Сирийский излом // Мир и политика http://mir-politika.ru/3097-siriyskiy-izlom.html

9. Бисмарк О. Письмо Леопольду фон Герлаху. 10 мая . 1856 г.

10. Маннергейм К.Г. Мемуары. М.: Вагриус, 1999.

11. Манойло А.В. Вооруженный мятеж в Украине может стать для России последним тревожным звонком // NB: Международные отношения. - 2014. - 2. - C. 24-37. DOI: 10.7256/2306-4226.2014.2.11137. URL: http://www.e-notabene.ru/wi/article_11137.html

12. Манойло A.В. Вооруженный мятеж в Украине: волна цветных революций идет на Россию // NB: Международные отношения. - 2014. - 3. - C. 27-35. DOI: 10.7256/2306-4226.2014.3.11498. URL: http:// www.e-notabene.ru/wi/article_11498.html

\footnotetext{
10 Бисмарк О. Письмо Леопольду фон Герлаху. 10 мая 1856 г.
}

11 См.: Маннергейм К.Г. Мемуары. М.: Вагриус, 1999. 
13. Бородинов Е.Н. Причины и следствия государственного переворота на Украине // NB: Международные отношения. - 2014. - 3. - C. 36-59. DOI: 10.7256/2306-4226.2014.3.11501. URL: http://www.enotabene.ru/wi/article_11501.html

14. Гушер А.И. Политический кризис на Украине // NB: Международные отношения. - 2014. - 3. - С. 1526. DOI: 10.7256/2306-4226.2014.3.11502. URL: http://www.e-notabene.ru/wi/article_11502.html

15. Гушер А.И. Вызовы и угрозы безопасности России // NB: Международные отношения. 2014. - 1. - C. 64-75. DOI: 10.7256/2306-4226.2014.1.10748. URL: http://www.e-notabene.ru/wi/ article_10748.html

16. Манойло А.В. Геополитическая картина современного мира // Национальная безопасность / nota bene. - 2013. - 5. - C. 149-155. DOI: 10.7256/2073-8560.2013.5.9394.

17. И. В. Бочарников Северо-Кавказский регион: проблемы и перспективы реализации государственной политики России // Международные отношения. - 2012. - 1. - С. 36-45.

\section{References}

1. MID Estonii podtverdil podlinnost' zapisi razgovora mezhdu Paetom i Eshton o sobytiyakh na Ukraine http:// russian.rt.com/article/23695

2. Priznanie ofitsial'nogo predstavitelya Gosdepa: vlozheniya v «maidan» $\$ 5$ mlrd http://communitarian.ru/ novosti/sng-i-sssr/priznanie_oficialnogo_predstavitelya_godepa_vlozheniya_v_maydan_5_mlrd_07012014/

3. Fond SShA priznal Ukrainu i Gruziyu nesostoyavshimisya gosudarstvami http://newsland.com/news/detail/ id/1232463/

4. Vernopoddanicheskie murashki Vitaliya Klichko http://polemika.com.ua/article-133823.html

5. Prizrak Sovetskogo Soyuza do sikh por pugaet Zapad http://newsland.com/news/detail/id/1299147/

6. Pomoshchnik gossekretarya SShA Viktoriya Nuland okonfuzilas' na ves' mir //Nezavisimaya gazeta. 7 fevralya $2014 \mathrm{~g}$.

7. Troyanskii kon' NATO pod vidom «ukrainskoi vesny» http://www.newscom.md/rus/troyanskij-kon_-natopod-vidom-ukrainskoj-vesni.html

8. Bocharnikov I.V. Siriiskii izlom // Mir i politika http://mir-politika.ru/3097-siriyskiy-izlom.html

9. Bismark O. Pis'mo Leopol'du fon Gerlakhu. 10 maya . $1856 \mathrm{~g}$.

10. Mannergeim K.G. Memuary. M.: Vagrius, 1999.

11. Manoilo A.V. Vooruzhennyi myatezh v Ukraine mozhet stat' dlya Rossii poslednim trevozhnym zvonkom // NB: Mezhdunarodnye otnosheniya. - 2014. - 2. - C. 24-37. DOI: 10.7256/2306-4226.2014.2.11137. URL: http://www.e-notabene.ru/wi/article_11137.html

12. Manoilo A.V. Vooruzhennyi myatezh v Ukraine: volna tsvetnykh revolyutsii idet na Rossiyu // NB: Mezhdunarodnye otnosheniya. - 2014. - 3. - C. 27-35. DOI: 10.7256/2306-4226.2014.3.11498. URL: http://www.e-notabene.ru/wi/article_11498.html

13. Borodinov E.N. Prichiny i sledstviya gosudarstvennogo perevorota na Ukraine // NB: Mezhdunarodnye otnosheniya. - 2014. - 3. - C. 36-59. DOI: 10.7256/2306-4226.2014.3.11501. URL: http://www.e-notabene. $\mathrm{ru} /$ wi/article_11501.html

14. Gusher A.I. Politicheskii krizis na Ukraine // NB: Mezhdunarodnye otnosheniya. - 2014. - 3. - C. 15-26. DOI: 10.7256/2306-4226.2014.3.11502. URL: http://www.e-notabene.ru/wi/article_11502.html

15. Gusher A.I. Vyzovy i ugrozy bezopasnosti Rossii // NB: Mezhdunarodnye otnosheniya. - 2014 - 1. - C. 64-75. DOI: 10.7256/2306-4226.2014.1.10748. URL: http://www.e-notabene.ru/wi/article_10748.html

16. Manoilo A.V. Geopoliticheskaya kartina sovremennogo mira // Natsional'naya bezopasnost' / nota bene. 2013. - 5. - C. 149-155. DOI: 10.7256/2073-8560.2013.5.9394.

17. I. V. Bocharnikov Severo-Kavkazskii region: problemy i perspektivy realizatsii gosudarstvennoi politiki Rossii // Mezhdunarodnye otnosheniya. - 2012. - 1. - C. 36-45. 